\title{
Social Class and Socioeconomic Status: Relevance and Inclusion in MPA-MPP Programs
}

\author{
Heather Wyatt-Nichol and Samuel Brown \\ University of Baltimore
}

Warren Haynes

Rutgers University

\begin{abstract}
Social equity has been challenged in recent years through increasing income inequality. The widening gap between the rich and the poor contributes to economic segregation among regions and neighborhoods and has a direct impact on public service delivery. This article examines declining mobility, economic segregation, and education to demonstrate the relevance of social class and socioeconomic status to the field of public administration. The potential for positive change lies in the willingness of scholars to advance social equity through representation, research, and pedagogy.
\end{abstract}

The U.S. economy has experienced a severe economic downturn in recent years, evident in the millions of home foreclosures, layoffs, and declining retirement portfolios. This "Great Recession" has a direct impact on the public sector as state and local governments are forced to cut budgets for various services due to declining revenues. Paradoxically, it is during times of economic decline and fiscal retrenchment that demand for public services increase. In addition to the economic crisis, there has been a gradual decline of the middle class-evident in declining mobility, increasing income inequality, and economic segregation.

As discussions on social equity have been dominated by race and gender, social class and declining mobility have been marginalized in premiere and mainstream journals of public administration. For example, Public Administration Review and American Review of Public Administration have been silent for over a decade on matters such as the impact of social class on the development of public policy (Oldfield, 2003). When socioeconomic status has been addressed, it has been narrowly framed within the policy realm of welfare reform and taxation policy. 
Mainstream public administration curricula also tend to marginalize issues of social class. Although the 2009 NASPAA Diversity Standard includes class as an element of diversity to promote "Diversity across the Curriculum," most member institutions continue to emphasize race, gender, and ethnicity. The omission of issues of social class and socioeconomic status in public administration programs has the potential to create blind spots among future public administrators and policy analysts.

An examination of the implications of inequality and declining mobility on public service illustrates the relevance of social class and socioeconomic status to the field of public administration, particularly within the context of social equity. The potential to advance social equity through representation and research is then considered, considered, followed by strategies to incorporate and assess issues of social class and socioeconomic status in MPA-MPP programs.

Relevance to the Field

\section{Social Equity}

The emergence of the New Public Administration Movement in the late 1960s, influenced by works of Dwight Waldo and H. George Frederickson, argued that the traditional school emphasized the institution rather than the problem to be solved by the institution. A commitment to social equity and the belief that administrators should be policy advocates are among the major themes of New Public Administration. Decades later, social equity gained greater acceptance within the field as the National Academy of Public Administration (NAPA) referred to social equity as the fourth pillar, following economy, efficiency, and effectiveness (NAPA, 2005). The conceptualizations and definitions of social equity have also become more refined over the years. The Standing Panel on Social Equity in Governance at NAPA defines social equity as:

The fair, just and equitable management of all institutions serving the public directly or by contract; the fair, just and equitable distribution of public services and implementation of public policy; and the commitment to promote fairness, justice, and equity in the formation of public policy (NAPA, n.d.).

Social equity, reflected through justice and fairness in the delivery of public services, is democracy in action. Social equity has been interpreted along the lines of procedural due process and fairness in distribution. The difficulty is that equitable distribution of resources is subject to interpretation and analysis of sometimes competing indicators: equity based on need, demand, preference, or willingness to pay (Lucy \& Mladenka, 1977; Wooldridge, 1998). More recently, NAPA's Standing Panel on Social Equity delineates measures of distributional 
equity along the lines of simple equality (equal distribution/water), differentiated equality (criteria or need/calls for service), targeted intervention (geographic concentration/health clinics), and redistribution (public assistance).

\section{Social Class and Socioeconomic Status}

The terms social class and socioeconomic status are used interchangeably throughout this article. Social class has been conceptualized through both structural and processual approaches, whereby the former interprets class as a matrix of fixed categories in which individuals move up or down a continuum while the latter interprets class as group identities shaped by common, shared experiences (Wright \& Shin, 1988). Structural approaches of class analysis typically measure social class through indicators of socioeconomic status such as income, occupation, and education. Weber (1947) categorized classes as working class, lowermiddle class, intelligentsia, and upper class. Similar to Weber, the stratification of classes demonstrated through Warner's class model (1949) divides classes into upper, middle, and lower, with subdivisions in each (upper-upper class, lowerupper class, upper-middle class, lower-middle class, upper-lower class, lower-lower class). Newer variations of Warner's model have since been produced by sociologists such as Gilbert (2002) and Thompson and Hickey (2005), and although the variations use different labels, the six hierarchical levels usually remain intact. In comparison, processual approaches to class analysis explore how individuals develop, interpret, and display class identities.

While processual approaches have tremendous value in class analysis, structural approaches are more appropriate to examine mobility. Mobility is broadly defined as the opportunity for one generation to increase relative earnings above the previous generation. The degree of mobility is often influenced by the opportunities available from one generation to the next. Advances in opportunity can be achieved through structural mobility and circulation mobility. Bok (1996) defines structural mobility as the product of economic growth, which involves an increase in the total supply of opportunities. In comparison, circulation mobility is defined as a matter of how fairly society distributes the opportunities that already exist.

The U.S. Census, the Current Population Survey, and the Panel Study of Income Dynamics are among the measures used to examine income and occupational stratification. The ranking of income is generally divided into five equal-sized groups or quintiles. This is done again for the incomes of individuals with the same characteristics in a later year. The quintile transition matrix is then used to compare the percentage of individuals who change income quintiles over a given period. Joseph Schumpeter's (1955) analogy of income distribution to a hotel fully occupied by different people at different times illustrates mobility. To get an accurate description of individual experience over a lifetime, one needs to know not only the size of the rooms but also the rate at which individuals switch 
rooms; therefore, the unequal distribution of income in any given year matters less if individuals are moving up or down the economic ladder over a lifetime.

\section{The Implications of Inequality and Declining Mobility on Public Service}

Box (2008) identifies socioeconomic inequality as a regressive value within our society that has been exacerbated over the last two decades as government "abandoned the idea of a systematic approach to problems of inequality" (p.18). The widening income gap between the rich and the poor in recent years provides evidence of increasing social inequality. Between 1979 and 2004, after-tax income of the poorest one-fifth of Americans increased by 9\%; however, the richest one-fifth of Americans saw an increase of 69\% (Sawhill \& Morton, 2008). Twenty percent of the richest households in the United States in 2004 earned over half of the total household income (Arcs \& Zimmerman, 2008), while 10\% of the richest families accounted for $70 \%$ of wealth (Haskins, n.d.). The disparities among the rich and poor, the shrinking middle class, and the recent economic crisis have a direct impact on the level and quality of public services available-it is here where social class and socioeconomic status become relevant to the field of public administration.

Numerous sources that document income stratification provide evidence of less upward mobility. The 1998 U.S. Census March Current Population Survey (CPS) reported that men between the ages of 25 and 34 in 1987 were the first to experience a lower median income than their fathers. More recently, men in their 30 s in 2004 earned an average 12\% less (adjusted for inflation) than their fathers at the same age a generation earlier (Isaacs, Sawhill, \& Haskins, 2008).

In addition to evidence of declining income compared to previous generations, upward mobility is less likely to occur for individuals born into poverty $-42 \%$ of children born in the bottom income quintile remain in the bottom quintile as adults (Isaacs et al., 2008). Overall, 70\% of those born in the bottom income quintile retain income status below middle class (Arcs \& Zimmerman, 2008), and only $7 \%$ rise to the top of the income distribution (Mazumder, 2008).

The widening gap between the rich and the poor contributes to economic segregation among neighborhoods, perpetuating the problem of inequality in the education and criminal justice system. Neighborhoods are often a reflection of socioeconomic status and result in economic segregation, which also has the potential to perpetuate racial and ethnic segregations as long as a disproportionate number of minorities are poor (Pebley \& Sastry, 2004). This economic segregation affects revenue bases and the level of services provided by municipalities. As a result, public administrators confront the challenge of how to provide adequate staffing and service levels when budgets are constrained. This includes the provision of adequate staffing of police and fire personnel, recruitment and retention of public school teachers in inner city neighborhoods or poor rural communities, and the geographic allocation and service hours of recreation centers and libraries. 
Studies have also demonstrated that residents of poor neighborhoods are more likely to suffer from health problems (Pebley \& Sastry, 2004). For example, residents of the City of Baltimore are more likely to die six years earlier than other Maryland residents (Linskey, 2008). According to the U.S. Census Bureau, the median income for the state of Maryland was the highest in the nation in 2008 at $\$ 70,545$. Similarly, a comparison of median household income from the U.S. Census Bureau's 2007 American Community Survey reveals that Howard County and Montgomery County were among the 10 highest median incomes in the United States for populations over 250,000 at $\$ 101,672$ and $\$ 91,835$ respectively (Bishaw \& Semega, 2008). In stark contrast however, the City of Baltimore is listed among the 10 lowest median incomes in the nation at \$36,949 (Bishaw \& Semega, 2008).

Access and quality of child- and family-related institutions such as child care, schools, and after-school programs are also a reflection of the socioeconomic status of neighborhoods. Despite state equalization efforts, there is evidence of disparities in public school revenues in every state. Funding disparities between low-income students and middle- to upper-class students persist (Orlofsky, 2002). According to a National Center for Education Statistics 1999 survey of the conditions of public school facilities, high-poverty schools ${ }^{1}$ were more likely to be in older buildings than low-poverty schools and were more likely to experience problems with the physical structure, such as heating, air conditioning, and plumbing (Corcoran, Evans, Godwin, Murray, \& Schwab, 2004). High-poverty schools were also more likely to have fewer books - an average of 1,600 fewer books at the elementary level and 3,500 fewer books at the high-school level (Phillips \& Chin, 2004).

Children of poor neighborhoods are also more likely to experience academic problems (Pebley \& Sastry, 2004). Achievement gaps based on socioeconomic status and race are also often evident at entry into kindergarten and first grade and can continue throughout the academic experience (Jencks \& Phillips, 1998). Using data from the National Assessment of Educational Progress (NAEP), Phillips and Chin (2004) found that fourth-grade African American students scored .80 standard deviations $(S D)$ below Caucasian students in reading and $.90 S D$ lower in math. When the socioeconomic status of school is considered (often measured via the percentage of students who qualify for subsidized school lunch), fourth-grade students in low-poverty schools exhibited reading scores one standard deviation higher than fourth-graders in high-poverty schools. Parental education also reveals a gap of $.90 S D$ between children of high-school dropouts and college graduates and $.60 S D$ between children of high-school graduates and college graduates (Phillips \& Chin, 2004). Others have found that students in central cities scored lower, regardless of the U.S. region (Stringfield \& Yakimowski-Srebnick, 2005).

These disparities often continue into higher education. Bok (1996) asserts that even with financial assistance through federal scholarship programs, children 
born into poverty are the least likely to attend college. Fifty-three percent of children from the top fifth of income earners will earn a college degree compared to only $11 \%$ from the bottom income quintile (Eckholm, 2008). Others contend that when working-class students do pursue a college degree, they often attend "third and fourth-tier institutions," which result in outcomes only slightly better than their peers who only completed high school (Aronowitz, 2004). Students from top income earners are overrepresented at Ivy League institutions-representing $75 \%$ of Harvard's freshmen class in 1999 (Raines \&McAdams, 2006). Similarly, only $3 \%$ of freshmen among 146 selective colleges and universities in the United States represent families at the bottom quarter of income distribution (Oldfield, Chandler, \& Johnson, 2006).

Within the judicial system, the NAPA Standing Panel on Social Equity report (2005) highlights the disparity in sentencing among urban minorities in possession of crack cocaine in comparison to possession of powder cocaine (more often seen among white middle-upper class) as one inequity in our legal system. According to the Bureau of Justice Statistics (1997), African Americans represent $36 \%$ of drug offense arrests and $59 \%$ of drug offense convictions. Similarly, one time-series analysis revealed that African American men were eight times more likely to be incarcerated than white men (Western, Kleykamp, \& Rosenfeld, 2004). Over time, studies have also demonstrated that lower-class males were more likely to be involved in crime than middle-class males, and that prison population increases with rising inequality (Western et al., 2004).

\section{STRATEGIES FOR INCLUSION}

One potential for change lies in the willingness of academicians to advance issues of social equity through representation, research, and pedagogy. Strategies for incorporating issues of social class and socioeconomic status into MPA-MPP programs include expanding admissions criteria, expanding research within the field of public administration, and incorporating issues of social class and socioeconomic status into core courses within the MPA-MPP curriculum.

\section{Representation}

As we prepare the next cadre of scholars and practitioners, socioeconomic status and the infusion of diversity into MPA-MPP programs must be explored. In the Chronicle of Higher Education Almanac Issue for 2010-2011, data reveal that one segment of the population makes up $85.7 \%$ of the nation's full professors and $83.5 \%$ of the executive, administrative, and managerial level employees in American college and university settings (Miller, 2010). Perhaps there is no better way to raise social class consciousness on the nation's college and university campuses than by making socioeconomic origins integral to the hiring process. Considering social class in faculty hiring can reduce classist assumptions on the part of faculty and staff, bring diverse perspectives to campus, and support 
student success. Democratizing higher education so that it represents a more complex reality and more diversity in terms of socioeconomic status will help privileged groups gain greater respect and appreciation for the values and survival skills their colleagues bring to campus.

While the U.S. Supreme Court has declared the use of numerous other demographic categories unconstitutional, the justices have never rejected a classification plan using socioeconomic status criteria (Kahlenberg, 1996). Class-oriented placement efforts fall under the rational basis legal test and do not require extensive supporting empirical evidence to validate their legitimacy (Oldfield \& Conant, 2001). Efforts to achieve diversity in higher education institutions are governed by the principles first articulated in Justice Powell's concurring opinion in Regents of the University of California v. Bakke (1978). The Court rejected a race-based affirmative action program at the University of California medical school as violating the Equal Protection Clause of the Fourteenth Amendment of the Constitution. Justice Powell's concurrence, however held out the possibility that the consideration of an applicant's race or ethnicity as part of a systematic effort to achieve a diverse student body could be permissible, provided that any favorable treatment of race and ethnicity did not operate as a quota and that race and ethnicity was "only one element in a range of factors a university properly may consider in attaining the goal of campus heterogeneity" (Gansler, 2008, p. 2.). Justice Powell's suggestion that certain affirmative action measures to promote a diverse core at an institution of higher education may be constitutionally acceptable.

Justice Powell's parameters of an allowable diversity plan were adopted by the Supreme Court in Grutter v. Bollinger (2003). The Court held that diversity in the higher education setting can be a compelling state interest. Thus, with the Grutter decision, the Court acknowledged the importance of diversity in higher education and offered institutions a narrow path for using affirmative action measures in their quest to achieve a diverse campus. If present judicial trends and legislative efforts continue, socioeconomic origins may be among the only acceptable diversity standards remaining in most jurisdictions (Oldfield, 2008).

Infusing social class and socioeconomic status into the fiber of MPA-MPP programs is critical, for social equity is vital to representative bureaucracy. A public service that closely matches the socio-demographic characteristics of the general population will more accurately reflect the public interest (Svara \& Brunett, 2004). Public administration programs should be the first to guarantee that the children of working-class parents have the same chance of becoming professors or practitioners as do the progeny of doctors, lawyers, accountants, and other professionals (Oldfield, 2010).

Admissions committees exercise full control over graduate student acceptance through review of individual files. The concept of merit might be expanded to also consider the obstacles students have overcome to qualify for review. Admissions committees should acknowledge the disadvantaged position of the lower-income 
or working-class student in terms of his or her parent's inability to invest in human capital (e.g., no extra money for music and art lessons or SAT prep classes; no time for trips to the museum). Admitting a cohort of MPA-MPP students from humble origins ensures that the bureaucracy embodies the interest of the less fortunate.

\section{Research}

A content analysis by Svara and Brunet (2004) of introductory Public Administration textbooks reveals that students are unlikely to encounter the term social equity in an introductory textbook. The two exceptions were introductory texts by Shafritz and Russell (who dedicate an entire chapter to social equity) and by Berkley and Rouse. Only two textbooks addressed social equity from a historical perspective. In contrast, most textbooks covered procedural due process from an administrative law perspective while discrimination and sexual harassment were covered in relation to human resources management. Svara and Brunet (2004) assert that other components of social equity are still lacking:

There are several gaps in social equity coverage. The need for administrators to understand how different cultures communicate and relate to government officials is noticeably absent in introductory texts. There is no coverage of distribution equity and ways to achieve or measure it. The consideration of the relative merits of equal distribution, some form of differentiated equality, redistribution, or equal results is missing. Finally, the texts do not link discussions of administrative ethics to the equity construct. (p. 106)

An examination of mainstream journals such as Public Administration Review and American Review of Public Administration have also neglected issues of social class and socioeconomic status in relation to diversity and social equity, the exception being welfare reform, or the impact of social class on the development of public policy (Oldfield, 2003). A content analysis by Oldfield et al. (2006) demonstrated that while Public Administration Review published five articles on social class in the 1960s and eight in the 1970s, only one article on social class was published in the 1980s, rising to a meager two articles in the 1990s. One consequence of ignoring social class and socioeconomic status in the classroom, journals, and textbooks is a diminishing ability to see the connection between inequality and public policy.

\section{Pedagogy}

The National Association of Schools of Public Affairs and Administration (NASPAA) adopted the Diversity Across the Curriculum (x.3) standard at its 2007 annual meeting. Class is included among the social identity categories, as stated in the written standard: 
Program activities must prepare students to work in and contribute to diverse workplaces and communities. Consequently, courses, curriculum materials, and other program activities should expose students to differences relating to social identity categories, such as race, ethnicity, gender, class, nationality, religion, sexual orientation, and disability. (NASPAA, 2006) ${ }^{2}$

Nevertheless, social class and socioeconomic status have generally received minimal attention in the curricula of most MPA-MPP programs. One recent study found that among the 92 program directors who responded (38\% response rate), 10 reported that their programs offered stand-alone courses on social class. In a separate content analysis of 50 member institutions, only one program offered a stand-alone course, Poverty, Inequality, and Public Policy, that addressed social class (Wyatt-Nichol \& Antwi-Boasiako, 2008). It does appear, however, that issues of social class and socioeconomic status are sometimes integrated into existing courses. For example, White (2004) examined 42 syllabi among 16 member institutions found that $21 \%$ addressed issues of class in existing courses.

Typical core courses where issues of social class and socioeconomic status are particularly salient include budgeting and public policy; however, other core courses can incorporate issues of social class and socioeconomic status through a variety of methods. Several faculty members in recent years have shared strategies to incorporate social equity into existing courses. Svara and Brunet (2004) recommend incorporating social equity into the introductory public administration survey courses by either dedicating a week of coverage or providing references to it throughout the semester. Wooldridge (1998) incorporates social equity into a master's level public administration theory course by introducing students to the themes of New Public Administration, which include commitment to social equity. Gooden and Myers (2004) recommend that students enrolled in public administration survey or policy courses examine "the historical development of a policy area with particular emphasis on identifying inequitable patterns" (p. 173).

Using a framework of measures of social equity along the categories of access and distributional equity, procedural fairness, quality and process equity, and outcomes (NAPA, 2005), faculty members are able to raise questions, identify issues, and develop assignments that specifically address problems arising from economic inequality (see Table 1).

\section{Administrative Law}

Students enrolled in an Administrative Law course quickly learn that discrimination or disparity of public service delivery based on socioeconomic status or social class is not unconstitutional, because "wealth is not a suspect classification under the equal protection clause for services that are not considered fundamental rights" (Lucy \& Mladenka, 1977, p. 105). Nevertheless, this does 
not prevent one from considering the impact (positive or negative) of court decisions on low-income or working-class Americans in cases dealing with labor (e.g., Lochner v. New York, 1905), economic development (e.g., Kelo v. City of New London, 2005), school funding (e.g., San Antonio Independent School District v. Rodriguez, 1973; Edgewood v. Kirby, 1989; Zelman v. Simmons-Harris, 2002), and the distribution of other public services (e.g., Hawkins v. Town of Shaw, 1971).

\section{Budgeting}

The implications of socioeconomic status are sometimes addressed in budgeting courses through an examination of progressive and regressive tax structures. While many faculty members might pursue the effects of tax policies on low-income working-class groups, others might provide greater attention to the subject by examining income, property, and sales taxes in terms of horizontal and vertical equity. One exercise that might be useful is to require students to examine the 2001 and 2003 tax cuts to assess the winners and losers.

Another way to incorporate issues of social class and socioeconomic status into a budgeting course is to examine resource allocation decisions. For example, students might consider several cities or independent school district budgets to examine sources of revenue, distribution of resources, and challenges and opportunities across neighborhoods within localities or independent districts. To make the exercise more realistic, students or teams could be asked to cut a percentage of their budget, justify their decisions, and describe how those decisions will affect low-income or working-class students.

The effects of tax policy on social equity are particularly appropriate for a public budgeting course. Alvez, Duarte, \& Timney (2008) contend that budgets would be improved if social equity were taken into account, particularly in areas of economic development or environmental policy. Similarly, Gianakis and Snow (2008) pose an essential question: "Is it possible to pursue social equity in the delivery of public programs while ignoring how they are funded?” (p. 69). They contend that social equity can be considered in the budget process and use the term supply side social equity to refer to tax policy that carefully considers such factors as ability to pay, capacity to redistribute, who bears the burden, and who benefits. By using a case-study approach to bring attention to social equity in relation to budgeting, Gianakis and Snow (2008) are able to increase awareness and understanding among students by utilizing a variety of examples, including the property tax burden on lower-income residents and the increasing reliance on user fees to prompt students to shift analysis from "can we?" to "should we?"

\section{Human Resources}

Human resources courses are conducive to addressing matters of social equity, particularly because issues of race and gender are addressed within the 
framework of public jobs as scarce resources and due process in hiring and promotion decisions. A human resources course could explore wage structures and staffing models by examining alternative working arrangements and the use of contingent employees. The increasing trend for public agencies to contract out for service delivery or hire temporary workers is often attributed to the reinvention movement, which calls for greater efficiency, flexibility, and responsiveness in human resources management. One exercise to increase awareness about the implications of reinvention initiatives is to require students to examine groups that are disproportionately affected when reductions in force occur (Wooldridge, 1998).

Another useful assignment to examine issues of social class and socioeconomic status is to require students to visit the Bureau of Labor Statistics website. There, students should examine and report the demographics of workers along the various categories of alternative working arrangements available through the Current Population Survey. Alternative working arrangements are divided into the following categories: independent contractors, on-call workers, temporary help agency workers, and workers provided by contract firms. Temporary agency workers are more likely to be minorities and high-school dropouts. In comparison, respondents categorized as "contract company workers" are predominantly white males with bachelor degrees (Bureau of Labor Statistics, 2001).

Students might also examine the number of contingent workers and policies governing the use of temporary and short-term employees in federal agencies. For example, there is often a misperception that contingent workers are employed only on a temporary or part-time basis. However, many "temporary workers" work full-time and sometimes maintain a temporary status for many years. Between 1991 and 2000, most of the temporary employees within the federal government worked full-time. Furthermore, many temporary employees within the federal government have maintained their status for many years. According to one former General Accounting Office report (GAO, 2002), the Office of Personnel Management (OPM) revised regulations limiting temporary employment to 2 years; however, several loopholes allow employees to work beyond the limit. Agency officials may request the OPM to extend the term. An agency can also convert or reappoint temporary employees if there has been a break in service for 3 days or less; and agencies may rehire a temporary employee after a break in service beyond 3 days, provided the appointment does not involve the same duties within the same subdivision of the agency.

\section{Program Evaluation}

Students might also examine the effects of specific job-training programs on the economic circumstances of low-income and working-class individuals. For example, critics assert that job-training programs have not reached intended groups, nor have such programs helped economically disadvantaged groups raise long-term hourly earnings. In fact, the national evaluation of welfare-to- 
work strategies published by the Department of Health and Human Services in 2000 found that participant earnings increased by less than $\$ 500$ a year (Lafer, 2002). Although numerous studies have been conducted on the effectiveness of job training, there is not enough evidence to conclusively evaluate the overall effectiveness of such programs. According to one Governmental Accountability Report (GAO, 2005) on job training, there is a lack of performance data on training providers and little is known about the outcome of participants under the restructured Workforce Investment Act.

\section{Public Management}

While public management courses address a broad range of subject matter, organizational performance is typically included. Performance measurement has been criticized for overemphasizing efficiency while marginalizing concerns for social equity (Box, 2008). Frederickson (2008) cites a study by Edward Jennings which found that only three federal departments, among 16 observed, addressed measures of social equity. Nevertheless, performance measurement techniques have the potential to contribute toward positive change. The National Academy of Public Administration (2005) asserts, "We can give issues of fairness the same creativity and attention we give to measuring performance and being efficient" (p. 9) and recommends including social equity considerations to assess performance. Oldfield (2003) contends that ASPA should encourage public organizations to collect and provide public access to data related to the distribution of wealth, as they currently do with other indicators. One assignment that may be useful for getting students to think about issues of social class and socioeconomic status is to require them to develop measures that examine the difference and effect of economic segregation on the delivery of public services.

\section{Public Policy}

In the area of public policy, students might examine a particular redistributive or distributive policy in depth to gain insight into the policy process and the policy effects on low-income or working-class families. For example, government investment in job-skills training has reached the public agenda during times of economic crisis, social reform, and welfare reform. Perception of the role of government and political acceptance of government investment in job training has varied throughout the years as a result of significant events, ranging from an expanded role of government after the Great Depression and Johnson's Great Society programs to changes in political representation and ideological shifts in an era of neoclassicism characterized by a reliance on the market with minimal government intervention. When the perceived need of government investment in job-training skills has reached the public agenda, a variety of policies have been formulated; they include the Works Progress Administration, the Civilian Conservation Corps, the Manpower Development 
and Training Act, the Comprehensive Education and Training Act, and the Job Training Partnership Act. In 1996 Congress passed the Personal Responsibility and Work Opportunity Reconciliation Act to emphasize the importance of job-skills training for high-school dropouts and welfare recipients. Two years later, Congress passed the Workforce Investment Act (to replace the Job Training Partnership Act).

Another useful strategy is to examine the role of a policy analyst through different lenses to examine issues of social class and socioeconomic status. For example, students might examine the roles of policy analysts as objective technician, client's advocate, and issue advocate (Wiemer \& Vining, 1992) for specific initiatives such as health care or immigration policy.

Romero (2006) incorporates philosophical frameworks among students in her policy analysis course. Students select a public problem and analyze policy alternatives through a variety of perspectives, ranging from libertarian to communitarian frameworks. The purpose of the project is to determine the best course of action from different, sometimes competing, perspectives. From a social equity perspective, Romero (2006) asserts that considerations of nontraditional value frameworks provide a greater depth of understanding among analysts:

Consider the fairly common criteria for assessing a policy's impact on the poorest citizens. That standard may be rendered more defensible and appropriate when utilized by an analyst familiar with Rawls' warrant for its value to society. Similarly, the objective for choosing a policy option that enhances neighborhood capacity may be more effective in the hands of an analyst with an understanding of the literature of the communitarian movement. Otherwise, criteria may merely be empty shells, platitudes that analysts are expected to consider but that exist in an authoritative vacuum and exert little moral or ethical weight. On the other hand, analysts trained to respect broad philosophical orientations will, as stipulated by the public or other clients, test policy alternatives against canons that contemplate the most enduring conceptual civic debates: the primacy of the individual versus society or the natural world; what constitutes "just" distributions; the process by which decisions should be reached, and so on. (p. 352)

Alvez et al. (2008) have also expanded policy considerations by approaching social equity from a global perspective and incorporating human rights theory. They contend that current policies have implications worldwide and that recognition of human rights contributes toward greater discernment in policy considerations that address a variety of problems such as health care or housing. 


\section{Research Methods}

A research methods class might examine the various measures of social class and socioeconomic status and assess the advantages and disadvantages of using different types of measures. For example, mobility can be measured by either occupation or income. The ranking of individual incomes from highest to lowest is also a common technique used to analyze mobility. The ranking is generally divided into five equal-sized groups or quintiles. This is done again for the incomes of individuals with the same characteristics in a later year. The quintile transition matrix is then used to compare the percentage of individuals who change income quintiles over a given period. In comparison, studies measuring occupations hierarchically rank occupational status to analyze the relationship between an individual's occupational origin (parental occupation) and destination.

This strategy has several benefits. First, students are introduced to levels of measurement as well as the conceptualization and operationalization of variables. Second, students are introduced to research organizations and data sets housed at various websites (e.g., Panel Study of Income Dynamics or the General Social Science Survey). Third, the data may be used to teach statistical techniques (e.g., regression analysis to examine factors that might contribute to either mobility or poverty).

\section{Summary AND CONCLUSION}

Social class and socioeconomic status are areas of interest that have been studied empirically, albeit mostly exclusively, as having the potentials for producing a plethora of positive and negative outcomes that influence individual behavior and the manner in which organizations respond to clients. While these variables are widely used in disciplines such as sociology and cultural studies, as social identity categories, there appears a mismatched paucity of interest in alternative, perhaps more viable, social equity indicators in the field of public administration.

Against this background, this article engages a methodological and theoretical review of research studies on the concepts of social class and socioeconomic status. The aim is to investigate the extent and value of the application of a broader set of social equity indicators by public service organizations to improve the efficiency and effectiveness of serving clients who present variations of social class and/or socioeconomic status. To achieve this objective, this article adopts a broader description of social equity, expanding to include the areas of social class and socioeconomic status, while simultaneously providing conceptual and pedagogical techniques for incorporating this expansive view of social equity in the traditional public administration curriculum. Within the field of public administration and public policy education, we can effect change through representation, research, and pedagogy. 
Table 1.

Incorporating Issues of Social Class and Socioeconomic Status into Core MPAMPP Courses

\begin{tabular}{|c|c|c|c|c|c|}
\hline 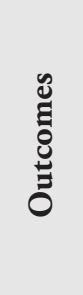 & \multicolumn{2}{|l|}{ 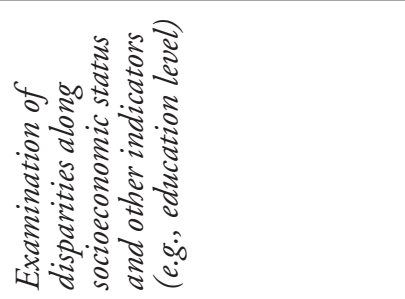 } & \multicolumn{3}{|c|}{ 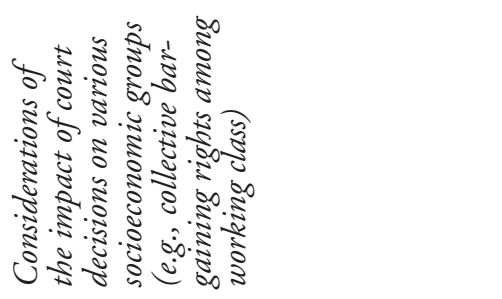 } \\
\hline 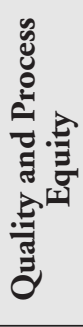 & 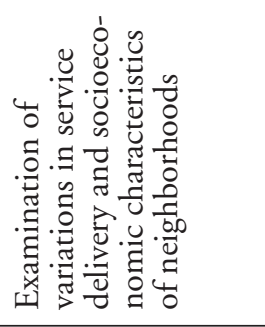 & & \multicolumn{3}{|c|}{ 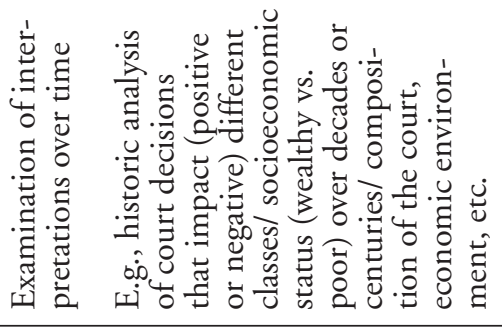 } \\
\hline 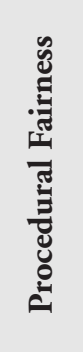 & 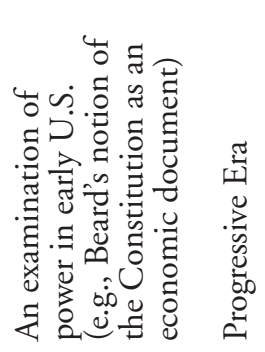 & 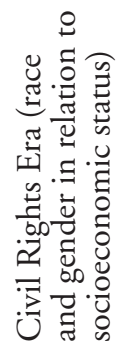 & \multicolumn{3}{|c|}{ 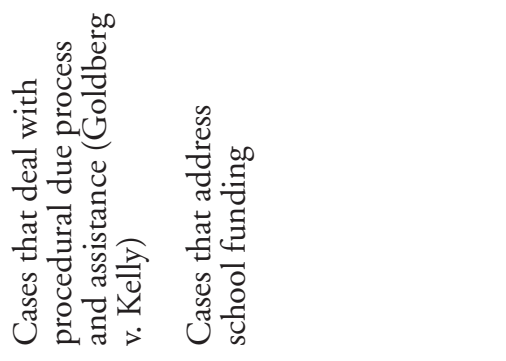 } \\
\hline 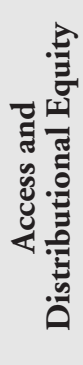 & \multicolumn{2}{|l|}{ 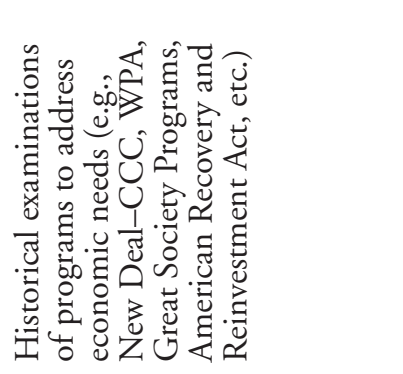 } & 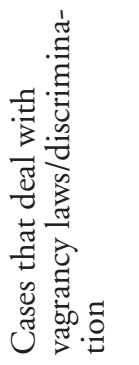 & 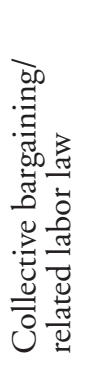 & 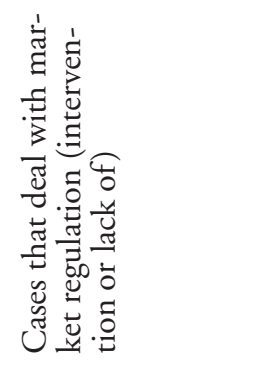 \\
\hline 芯 & \multicolumn{2}{|l|}{ 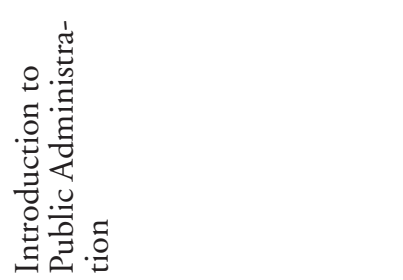 } & \multicolumn{3}{|l|}{ 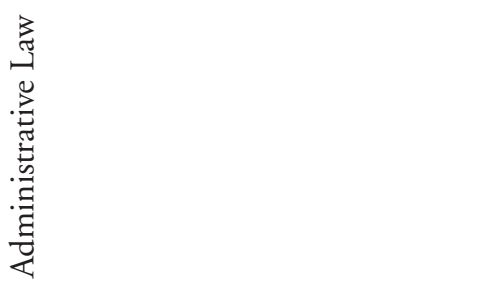 } \\
\hline
\end{tabular}


Table 1.

Continued

\begin{tabular}{|c|c|c|c|c|}
\hline $\begin{array}{l}\mathscr{U} \\
\tilde{\Xi} \\
\stackrel{0}{\Xi} \\
0\end{array}$ & 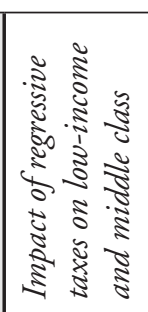 & 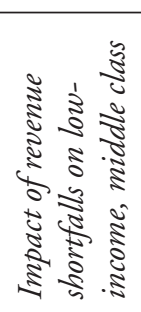 & \multicolumn{2}{|l|}{ 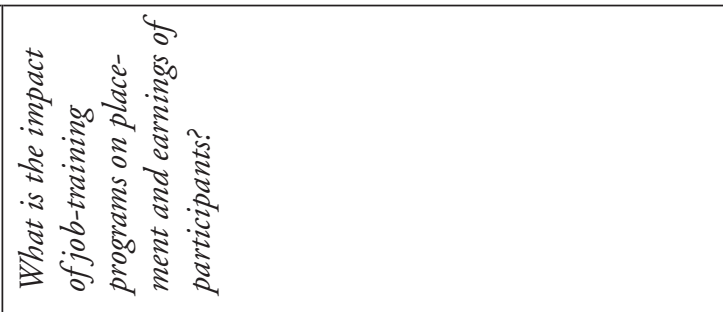 } \\
\hline 然 & \multicolumn{2}{|c|}{ 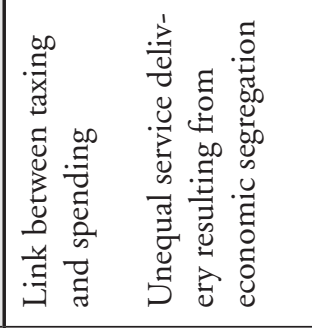 } & \multicolumn{2}{|c|}{ 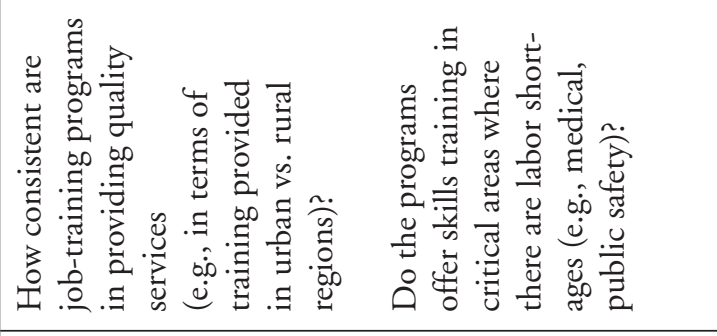 } \\
\hline 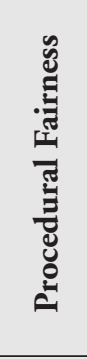 & \multicolumn{2}{|c|}{ 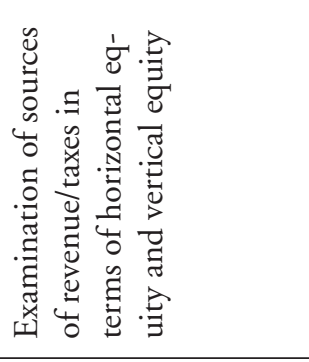 } & \multicolumn{2}{|l|}{ 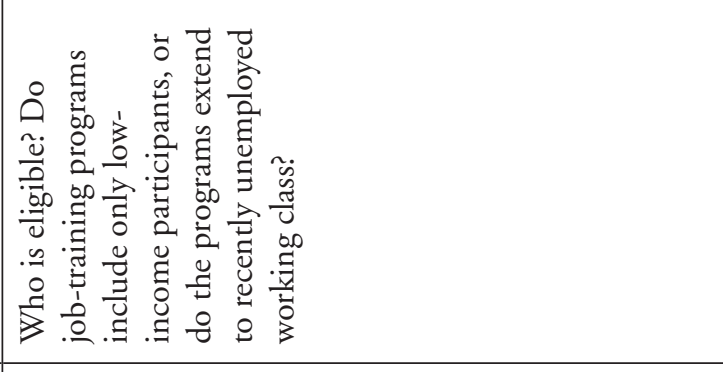 } \\
\hline 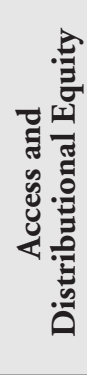 & 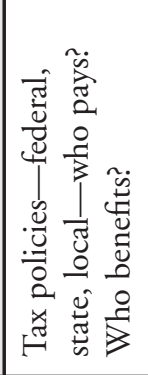 & 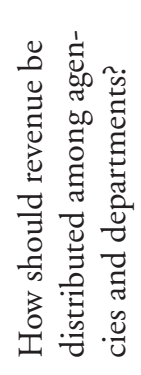 & 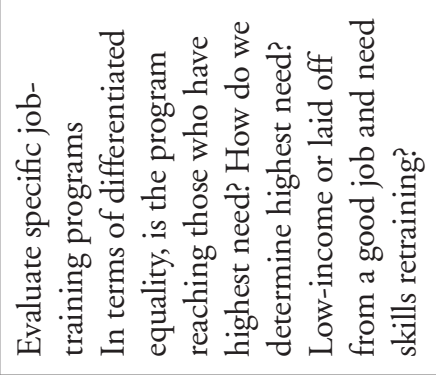 & 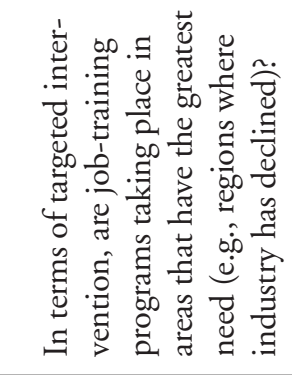 \\
\hline 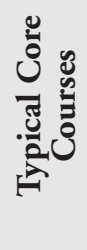 & 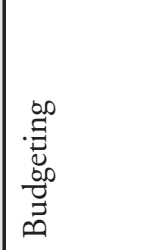 & & 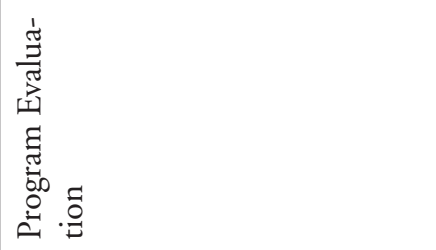 & \\
\hline
\end{tabular}


Table 1.

Continued

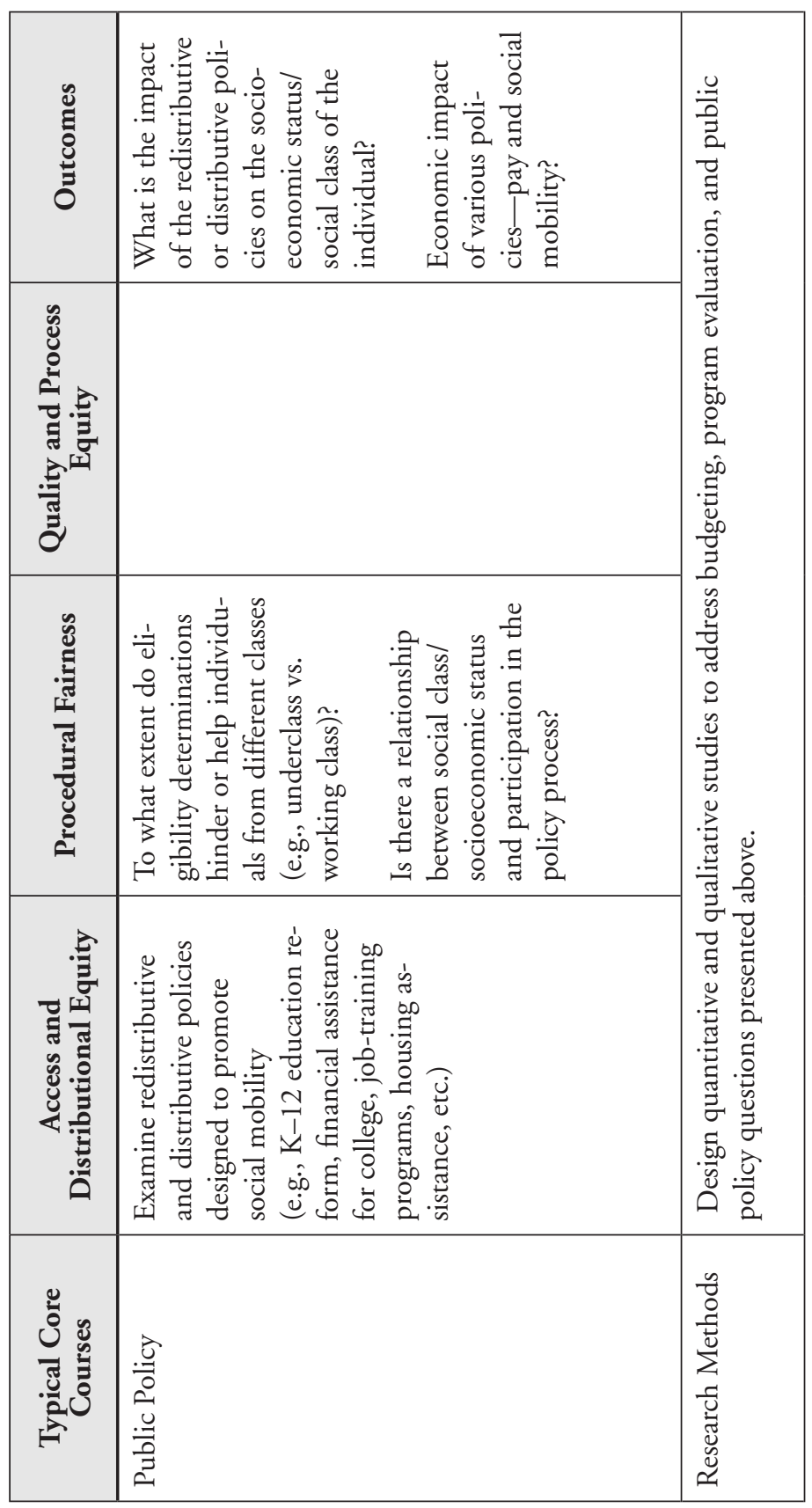




\section{Social Class and Socioeconomic Status}

\section{FOOTNOTES}

1 A high-poverty school is defined as one in which $70 \%$ or more students are eligible for subsidized school lunch.

2 At the Annual Business Meeting in Seattle, Washington (October 12, 2007), NASPAA voted to approve the proposed Diversity Across the Curriculum Standard. Age and Veteran Status were also incorporated as components of diversity.

\section{REFERENCES}

Alvez, J., Duarte, S., \& Timney, M. (2008). Human rights theory as a means for incorporating social equity into the public administration curriculum. Journal of Public Affairs Education, 14(1), 51-66.

Arcs, G., \& Zimmerman, S. (2008, November). U.S. intergenerational economic mobility from 1984 to 2004: Trends and implications. Economic Mobility Project, Pew Charitable Trusts. Retrieved from http://www.economicmobility.org/reports_and_research/other?id=0005

Aronowitz, S. (2004). Against schooling: Education and social class. Social Text, 22(2), 13-35.

Bartels, L. M. (2005). Homer gets a tax cut: Inequality and public policy in the American mind. Perspectives on Politics, 3(1), 15-31.

Bishaw, A., \& Semega, J. (2008). Income, earnings, and poverty data from the 2007 American Community Survey (Report No. ACS-09). U.S. Census Bureau, Retrieved from http://www.census. gov/prod/2008pubs/acs-09.pdf

Bok, D. (1996). The state of the nation: Government and the quest for a better society. Cambridge, MA: Harvard University Press.

Box, R. (2008). Making a difference: Progressive values in Public Administration. Armonk, NY: M.E. Sharpe.

Corcoran, S., Evans, W. N., Godwin, J., Murray, S. E., \& Schwab, R. M. (2004). The changing distribution of education finance, 1972-1997. In K. M. Neckerman (Ed.), Social Inequality (pp. 433-465). New York: Russell Sage Foundation.

Eckholm, E. (2008, February 19). Higher education gap may slow economic mobility. New York Times. Retrieved from www.nytimes.com/2008/02/20/us/20mobility.html

Frederickson, H.G. (2008). Social equity in the twenty-first century: An essay in memory of Phillip J. Rutledge. Journal of Public Affairs Education, 14(1), ii-vii.

Gansler, D. (2008, May 15). Senate Bill 438 and House Bill 905. Letter to Martin J. O'Malley, Governor of Maryland. Annapolis, MD: Office of the Attorney General.

Gianakis, G., \& Snow, D. (2008). Teaching "supply-side” social equity in MPA programs. Journal of Public Affairs Education, 14(1), 67-77.

Gilbert, D. (2002). The American class structure: In an age of growing inequality. Belmont, CA: Wadsworth.

Gooden, S., \& Myers, S., Jr. (2004). Teaching social equity in the MPA: Reflections on the social equity symposium. Journal of Public Affairs Education, 10(2), 155-175. 
Grutter v. Bollinger, 539 U.S. 306 (2003).

Gulick, L. (1937/1973). Notes on the theory of organization. In L. Gulick \& Urwick (Eds.), Papers on the science of administration. Clifton, NY: Augustus Kelley.

Haskins, R. (n.d.). Wealth and economic mobility. Economic Mobility Project, Pew Charitable Trusts. Retrieved from www.economicmobility.org/assets/pdfs/EMP_WealthandEconomicMobility_ChapterIV.pdf

Isaacs, J. B., Sawhill, I. V., \& Haskins, R. (2008, February). Getting ahead or losing ground: Economic mobility in America. Economic Mobility Project, Pew Charitable Trusts. Retrieved from www.economicmobility.org/assets/pdfs/PEW_EMP_GETTING_AHEAD_FULL.pdf

Jencks, C., \& Phillips, M. (1998). The black-white test score gap. Washington, DC: Brookings Institution Press.

Kahlenberg, R. (1996). The remedy. New York: Basic Books.

Lucy, W. H., \& Mladenka, K. R. (1977). Equity and urban service distribution. Unpublished manuscript submitted to the Urban Management Curriculum Development Project. Washington, DC: National Training and Development Service. Retrieved from www.people.vcu.edu/ -bwooldri/ courses/soc_equ.html

Lafer, G. (2002). The job training charade. Ithaca: Cornell University Press.

Linskey, A. (2008, October 7). Death figures show need for action. The Baltimore Sun, p. 7.

Mazumder, B. (2008, May). Upward intergenerational economic mobility in the United States. Economic Mobility Project, Pew Charitable Trusts. Retrieved from www.economicmobility.org/assets/ pdfs/PEW_EMP_UPWARD_INTERGENERATIONAL.pdf

Miller, M. (2010). The profession: More pressure on faculty members from every direction. Chronicle of Higher Education Almanac Issue 2010-11, LVII(1), 17-24.

National Academy of Public Administration, Standing Panel on Social Equity in Governance. (2008, March 15). Definition of social equity. Retrieved from www.napawash.org/fellows/standing-panels/ standing-panel-on-social-equity-in-governance/

. (2005). Sounding the call to the Public Administration community: The social equity challenges in the U.S. Retrieved from www.napawash.org/aa_social_equity/index.html

National Association of Schools of Public Affairs and Administration. (2006, October). Diversity Standard, Draft. Retrieved from http://diversitystandard.blogspot.com/2006/12/proposed-naspaadiversity-standard.html

Oldfield, K. (2003). Social class and public administration: A closed question opens. Administration \& Society, 35(4), 438-461.

. (2008). Are the nation's leading Political Science programs practicing egalitarian values espoused in American democracy in an age of rising inequality, and if not, how can they? Political Science and Politics, XLI(3), 567-573.

. (2010). Our cutting edge isn't cutting it: Why Public Administration should be the first discipline to implement a social class-based affirmative action plan for hiring professors. Administration and Society, 41(8), 1016-1038. 


\section{Social Class and Socioeconomic Status}

Oldfield, K., Chandler, G., \& Johnson, R. G., III. (2006). Social class, sexual orientation, and toward proactive social equity scholarship. American Review of Public Administration, 36(2), 156-172.

Oldfield, K., \& Conant, R. (2001). Professors, social class, and affirmative action. Journal of Public Affairs Education, 7(3), 171-185.

Orlofsky, G. F. (2002). New school finance data shows deep inequities, but gaps in some states decreasing. The Education Trust. Retrieved from www.edtrust.org/dc/press-room/press-release/new-schoolfinance-data-analysis-shows-deep-inequities-but-gaps-in-some-

Pebley, A. R., \& Sastry, N. (2004). Neighborhoods, poverty, and children's well-being. In K. M. Neckerman (Ed.), Social inequality (pp. 119-145). New York: Russell Sage Foundation.

Phillips, M., \& Chin, T. (2004). School inequality: What do we know? In K. M. Neckerman (Ed.), Social inequality (pp. 467-519). New York: Russell Sage Foundation.

Raines, J. \& McAdams, C. B. (2006). College and social class: The broken promise of America. Cross Currents, 56, 1. Retrieved from www.crosscurrents.org/Rainesspring2006.htm

Regents of the University of California v. Bakke, 438 U.S. 265 (1978).

Romero, F. S. (2006). Value frameworks in the policy analysis course: An application exercise. Journal of Public Affairs Education, 12(3), 347-360.

Sawhill, I. V., \& Morton, J. E. (2008). Economic mobility: Is the American dream alive and well? Economic Mobility Project, Pew Charitable Trusts. Retrieved from www.economicmobility.org/assets/ pdfs/EMP_American_Dream.pdf

Schumpeter, J. (1955). Imperialism and social classes. New York: Meridian Books.

Stringfield, S. C., \& Yakimowski-Srebnick, M. E. (2005). Promise, progress, problems, and paradoxes of three phases of accountability: A longitudinal case study of the Baltimore City public schools. American Educational Research Journal, 42(1), 43-75.

Svara, J. H., \& Brunet, J. (2004). Filling in the skeletal pillar: Addressing social equity in introductory courses in Public Administration. Journal of Public Affairs Education, 2, 99-109.

Thompson, W., \& Hicky, J. (2005). Society in focus. Boston: Pearson, Allyn \& Bacon.

U.S. Department of Justice, Bureau of Justice Statistics. (1997). Sourcebook of criminal justice statistics (NCJ 165361). Retrieved from http://bjs.ojp.usdoj.gov/index.cfm?ty=pbdetail\&iid=1428

U.S. Department of Labor, Bureau of Labor Statistics. (2001). Contingent and alternative employment arrangements (DOL Publication No. USDOL 01-153). Washington, DC: U.S. Government Printing Office.

U.S. General Accounting Office. (2002). Federal employees: OPM data do not identify if temporary employees work for extended periods (GAO Publication No. GAO 02-296). Washington, DC: U.S. Government Printing Office

U.S. Government Accountability Office. (2005, June). Workforce Investment Act: Substantial funds are used for training, but little is known nationally about training outcomes (GAO Publication No.GAO-05-605). Washington, DC: U.S. Government Printing Office. 
Warner, W. L., Meeker, M., \& Eells, K. (1949). Social class in America: A manual of procedure for the measurement of social status. Chicago: Science Research Associates, Inc.

Weber, M. (1947). The theory of social and economic organization (T. Parsons, Trans.). New York: Oxford University Press.

Weimer, D. L., \& Vining, A. R. (1992). Policy analysis: Concepts and practice (2nd ed.). Englewood Cliffs, NJ: Prentice Hall.

Western, B., Kleykamp, M., \& Rosenfeld, J. (2004). Crime, punishment, and American inequality. In K. M. Neckerman (Ed.), Social inequality (pp. 771-796). New York: Russell Sage Foundation.

White, S. (2004). Multicultural MPA curriculum: Are we preparing culturally competent administrators. Journal of Public Affairs Education, 10(2), 111-123.

Wooldridge, B. (1998). Protecting equity while reinventing government: Strategies for achieving a fair distribution of the costs and benefits of the public sector. Journal of Public Management and Social Policy, 4(1), 6.

Wright, E. O. \& Shin, K. Y. (1988). Temporality and class analysis. Sociological theory, 6, 58-84.

Wyatt-Nichol, H., \& Antwi-Boasiako, K. B. (2008). Diversity across the curriculum: Perceptions and practices. Journal of Public Affairs Education, 14(1), 79-90. 
Heather Wyatt-Nichol, PhD, is an assistant professor in the College of Public Affairs at the University of Baltimore. She earned a PhD in public policy and administration from Virginia Commonwealth University and an MPA from Old Dominion University. Her research interests include diversity management, ethics, family-friendly workplace policies, organizational behavior, and social equity.

Samuel L. Brown, PhD, currently serves as director of the Masters of Public Administration Program in the School of Public Affairs at the University of Baltimore. In addition, he is a tenured associate professor and senior fellow to the William Donald Schafer Center for Public Policy in the College of Public Affairs, at the University of Baltimore.

Warren Errol Haynes is a postdoctoral associate in the Department of Public Policy and Administration at Rutgers University-Camden. He has over 15 years experience in higher education, state and local government, and the nonprofit sector. He earned his DPA in public administration from the University of Baltimore, MS degree in Higher Education Administration, MCRP degree in city and regional planning, and a BA degree in political science. His research interests include education policy, social equity, implementation, nonprofit management, and community development. 